\title{
Training needs assessment: identification of competence fields for the dismantling of nuclear power plants
}

\author{
Lisa Thomaschewski ${ }^{1}$, Benjamin Weyers ${ }^{2}$, and Annette Kluge ${ }^{1}$ \\ ${ }^{1}$ Department of Work-, Organizational-, and Business Psychology, Ruhr University Bochum, 44780, Germany \\ ${ }^{2}$ Department IV, Computer Science, Human-Computer Interaction, University of Trier, 54296, Germany
}

Correspondence: Lisa Thomaschewski (lisa.thomaschewski@rub.de)

Published: 10 November 2021

\begin{abstract}
The dismantling of nuclear facilities is a continuous process of change encompassing the complete site. Thereby, the focus changes from a stable and standardized operational phase to a situation characterized by constant changes in the facility as well as in the facility organization. Thus, employees and managers are confronted with a markedly changed working environment: processes and methods must be continuously reevaluated and adapted, qualification requirements change or shift and new interfaces emerge. Furthermore, compared to the operational phase, the regulatory depth is reduced, decisions must be made faster and more flexible and the mode of operation changes from hierarchically organized routine standard operational procedures to an efficiency-orientated project-based mode of operation with limited resources at the same time. To make dismantling efficient and safe, this change should be actively managed by a change project in terms of the human technology organization approach (MTO approach, Strohm and Ulich, 1999).

Against this background, our BMBF-funded collaboration project ("Die Kompetenzen von Führungskräften und MitarbeiterInnen für den Rückbau stärken - Rückbaukompetenzen"; funding number 15S9426A) aims to identify the dismantling-related requirement changes and the associated competence shifts as well as to develop and support the changed roles of managers and employees by scientifically based training (Goldstein and Ford, 2002; IAEA, 1998). Thereby, seminar-based training (knowledge-based and demonstration-based, e.g., Sitzmann and Weinhardt, 2019) will be complemented by exercise-based and experience-based training (Cannon-Bowers and Bowers, 2010) with multimodal mixed reality applications, which allow experience-based learning with the help of virtual reality-based representations (via data glasses, tablet or PC) and can be adapted to the individual usage and learning style preferences of the trainees. The training will be developed and implemented in cooperation with our project partner GfS (Gesellschaft für Simulatorschulung $\mathrm{mbH}$ ). After project completion, the GfS will provide the training to nuclear power plant operators and, if necessary, develop them so that a sustainable contribution to the preservation of the specialized knowledge in the nuclear energy sector is achieved.

To identify the needs for dismantling-relevant training objectives and competencies in the first step, a document analysis (safety alerts and monthly reports from our project partner PreussenElektra GmbH and over 500 reportable incidents from 28 nuclear power plants from 2012-2020), as well as 10 expert interviews, were conducted. The document analysis was used to investigate the incidents for (1) differences between operational phase and decommission, (2) differences in events between in-house and contractor personnel and to identify the incidents with the highest frequencies.

The objective of the expert interviews was the qualitative context analysis as well as the identification of dismantling-relevant competence fields. The analysis allowed us to identify nine dismantling-related competence fields for employees and managers and a further three specifically for managers. These 12 competence fields will be discussed and defined in more detail in further interviews with approximately 20 managers and 30 employees. Based on these findings, training objectives will be formulated and training content designed.

The presentation outlines the analysis described above as well as the identified fields of competence and sketches the further procedure of the collaborative project.
\end{abstract}


Kurzfassung. Der Rückbau kerntechnischer Anlagen lässt sich als kontinuierlicher Veränderungsprozess beschreiben, der den kompletten Standort umfasst. Mit Abschaltung der nuklearen Einrichtung wechselt der Fokus von einem stabilen Leistungsbetrieb mit wiederkehrenden Aufgaben und standardisierten Methoden in der Anlage zu einer Situation, die durch ständige Veränderungen der Anlage sowie der Anlagenorganisation charakterisiert ist. Dadurch sind Mitarbeitende und Führungskräfte mit einem deutlich veränderten Arbeitsumfeld konfrontiert: Abläufe und Methoden müssen kontinuierlich neubewertet und angepasst werden, Qualifikationsanforderungen ändern oder verschieben sich, es entstehen neue Schnittstellen. Zusätzlich wird die Regelungstiefe im Vergleich zum Leistungsbetrieb geringer, Entscheidungen müssen schneller und flexibler getroffen werden, die Arbeitsweise wechselt von hierarchisch organisierten routinierten Standard Operation Procedures zu einer projektbasierten Arbeitsweise, die effizienz- und projektorientiert ist, bei gleichzeitig limitierten Ressourcen. Um den Rückbau effizient und sicher zu gestalten, sollte dieser Wandel durch ein Change Projekt im Sinne der Mensch-Technik-Organisation-Ansatzes (MTO Ansatz, Strohm und Ulich, 1999) aktiv gesteuert werden.

Vor diesem Hintergrund zielt unser vom BMBF-gefördertes Verbundprojekt (,Die Kompetenzen von Führungskräften und MitarbeiterInnen für den Rückbau stärken - Rückbaukompetenzen“; Fördernummer 15S9426A) darauf ab, die rückbaubedingten Anforderungsveränderungen und damit einhergehenden Kompetenzverlagerungen zu identifizieren sowie die veränderten Rollen von Führungskräften und Mitarbeitenden durch wissenschaftlich entwickelte Trainingsmaßnahmen zu unterstützen (Goldstein und Ford, 2002; IAEA, 1998). Dabei sollen seminar-basierte Trainingsangebote (wissensbasiert und demonstrationsbasiert, z.B. Sitzmann und Weinhardt, 2019) um übungs- und erfahrungsbasierte Trainingsmethoden (Cannon-Bowers und Bowers, 2010) mit multimodalen Mixed Reality Anwendungen ergänzt werden, welche erfahrungsbasiertes Lernen mit Hilfe von Virtual Reality-basierten Darstellungen (via Datenbrille, Tablet oder PC) erlauben und auf die individuellen Nutzungs- und Lernstilpräferenzen der Trainees angepasst werden können. Die Trainings werden im Rahmen des Projektes gemeinsam mit unserer Projektpartnerin GfS (Gesellschaft für Simulatorschulung mbH) entwickelt und durchgeführt. Nach Projektabschluss wird die GfS die entwickelten Trainings Betreibern von Kernkraftanlagen anbieten und ggf. weiterentwickeln, so dass ein nachhaltiger Beitrag zum Erhalt der Fachkunde im Kernenergieberiech geschaffen wird.

Um im ersten Schritt den Bedarf rückbaurelevanter Trainingsziele und Kompetenzen zu identifizieren, wurden eine Dokumentenanalyse (Safety Alerts und meldepflichtige Ereignisse unserer Projektpartnerin PreussenElektra GmbH und über 500 meldepflichtige Ereignisse von 28 Kernkraftwerken der Jahre 2012-2020) sowie 10 Expertengespräche durchgeführt. Anhand der Dokumentenanalyse wurden die Ereignisse auf Unterschiede zwischen (1) Rückbau und Leistungsbetrieb und (2) Eigen- und Fremdpersonal untersucht, sowie die Ereignisse mit der größten Häufigkeit identifiziert.

Ziel der Expertengespräche war die qualitative Kontextanalyse sowie Identifikation rückbaurelevanter Kompetenzfelder. Durch diese Analyse konnten wir neun rückbaubezogene Kompetenzfelder für Mitarbeitende und Führungskräfte und weitere drei spezifisch für Führungskräfte identifizieren. Diese insgesamt 12 Kompetenzfelder werden in weiteren Interviews mit ca. 20 Führungskräften sowie 30 Mitarbeitenden näher erörtert und definiert. Basierend auf diesen Erkenntnissen sollen im Anschluss Trainingsziele formuliert und Trainingsmaßnahmen gestaltet werden.

Der Beitrag präsentiert die oben beschriebene Analyse sowie die identifizierten Kompetenzfelder und skizziert das weitere Vorgehen des Verbundprojektes.

Financial support. This research has been supported by the Bundesministerium für Bildung und Forschung (grant no. 15S9426A).

\section{References}

Cannon-Bowers, J. and Bowers, C.: Synthetic learning environments: On developing a science of simulation, games, and virtual worlds for training, in: Learning, training, and development in organizations, edited by: Kozlowski, S. W. J. and Salas, E., Routledge/Taylor \& Francis Group, New York, 229261, https://doi.org/10.4324/9780203878385, 2010.
Goldstein, I. L. and Ford, J. K.: Training in organizations: Needs assessment, development, and evaluation, 4th Edn., Cengage Learning, Wadsworth, 2002.

IAEA: Experience in the use of systematic approach to training (SAT) for nuclear power plant personnel, IAEATECDOC-1057, available at: https://www-pub.iaea.org/MTCD/ Publications/PDF/te_1057_prn.pdf (last access: 14 June 2021), 1998.

Sitzmann, T. and Weinhardt, J. M.: Advancing training for the 21st century, Hum. Resour. Manage. R., 29, 137-139, https://doi.org/10.1016/j.hrmr.2018.07.005, 2019. 
Strohm, O. and Ulich, E.: Ganzheitliche Betriebsanalyse unter Berücksichtigung von Mensch, Technik, Organisation (MTOAnalyse), in: Handbuch psychologischer Arbeitsanalyseverfahren (Mensch - Technik - Organisation), 14, edited by: Dunckel, H., vdf Hochschulverlag AG an der ETH Zürich, 319325, 1999. 